\title{
CORRELATIONS BETWEEN THE LEVELS OF ELEMENTS IN THE BLOOD AND SOME PHYSIOLOGICAL / BIOCHEMICAL PARAMETERS IN FEMALE ROADSIDE WORKERS IN ILE-IFE, NIGERIA
}

\author{
Oketayo, O. O. ${ }^{* 1}$, Ojo, J. O. ${ }^{1,2}$, Salawu, A. A. ${ }^{3}$, Aboderin, O. ${ }^{4}$, Adewusi, S. A. ${ }^{5}$ \\ ${ }^{1}$ Department of Physics, ${ }^{4}$ Medical Microbiology and ${ }^{5}$ Chemistry \\ Obafemi Awolowo University, Ile-Ife, Nigeria \\ ${ }^{3}$ Department of Chemical Pathology, Obafemi Awolowo University Teaching Hospital Complex, Ile-Ife, Nigeria \\ ${ }^{2}$ Present Address: Department of Physics, Federal University Oye-Ekiti, Nigeria. \\ *Author for Correspondence. E-mail address: oketayodele@gmail.com, Tel: +234 8068565178
}

(Received: $25^{\text {th }}$ May, 2017; Accepted: $23^{\text {rd }}$ September, 2018)

ABSTRACT

\begin{abstract}
This work determined the levels of $\mathrm{As}, \mathrm{Cd}, \mathrm{Cu}, \mathrm{Hg}, \mathrm{Pb}, \mathrm{Se}$ and $\mathrm{Zn}$ in the blood of sixty-two Nigerian women roadside workers in Ile-Ife using Inductively-Coupled Plasma Mass Spectrometry and Direct Mercury Analyzer and investigated the toxic metal correlation with some physiological / biochemical parameters. Body fat was estimated using bioelectrical impedance and isotope dilution methods. The results showed that arsenate correlated ( $\mathrm{p} \leq 0.05)$ with total cholesterol $(\mathrm{TC})$ and plasma creatinine (P.Cr) in underweight subjects, P.Cr in obese subjects and with creatinine clearance and urinary creatinine in all the subjects. Cd correlated with low density lipid-cholesterol (LDL-C) and TC in underweight, waist and waist/hip ratio in overweight and packed cell volume in obese subjects while $\mathrm{Hg}$ had a high correlation factor with LDL-C in overweight and triglycerides and TC in obese subjects. Pb correlated highly with age and total body water in obese subjects. These indicated that interactions between trace elements and the physiological / biochemical parameters are influenced by the nutritional status of the individual subjects and possibly provide a basis for determining the effects of these toxic elements on the exposed subjects.
\end{abstract}

Keywords: Correlation, Blood Trace Elements, Nutritional Status

\section{INTRODUCTION}

One of the global problems confronting mankind is exposure to environmental pollutants/chemicals, most especially toxic elements, resulting in negative impacts on the quality of human life (FDA/EPA, 2004). Vehicular exhaust, amongst others, is believed to account for more than $80 \%$ of this pollution in some urban centers in Nigeria (Obioh et al., 1993). Apart from fossil fuel combustion, studies have shown that pollution by heavy metals such as $\mathrm{Cd}$, $\mathrm{Pb}, \mathrm{Fe}, \mathrm{Ni}, \mathrm{Co}, \mathrm{Mo}$, As and $\mathrm{Zn}$ are associated with the wear and tear in tires, brake pads, lead weights for wheel balancing, corrosion of bushings etc. of automobiles (Muschack, 1990; Viklander, 1998; USEPA, 1997). The levels of these pollutants or toxic elements such $\mathrm{Pb}$ in air (Agbo, 1997), roadside topsoil (Fakayode, 2003; Ogunsola and Akeredolu, 1994) or run-off water sediments from paved roads (Adekunle et al. 2009) have been found to vary according to traffic volume and distance from high ways. It has been established that blood samples from traffic wardens contain these pollutants depending on total length of exposure to these damaging heavy metal pollutants.

In developing countries such as Nigeria, women of low socio-economic status are particularly exposed to vehicular elemental pollution by virtue of extensive street-related activities such as street trading, which is associated with poverty since most cannot afford regular shops in designated centres. These women, more often than not, are of child bearing age and often go into their trading post with infants and pre-school children. According to Antham et al (2006), continual exposure can affect the lungs of growing children and may aggravate or complicate medical conditions in elderly. Furthermore, some of these women become pregnant from time to time. The exposure to these pollutants has been found to affect the fetus (ASTDR, 1999). For instance, maternal blood crosses the placenta and put the fetus at risk. Increasing evidence indicates that maternal lead can adversely affect fetus viability as well as fetal and early childhood development (ATSDR, 1999). This makes environmental exposure in women of child-bearing age more precarious because such women can become a 
source of exposure to fetuses and infants through placental exchange and during lactation.

There is a growing national and international interest in the probable effects of exposure to pollutants through road side economic activities and its relationship with the nutritional status of subjects thus exposed. Vahter (2007) provided evidence of the association between nutrients (1carbon metabolism) and arsenic toxicity in Bangladeshi women while the relationship between heavy metals (especially blood $\mathrm{Pb}$ levels and urine $\mathrm{Hg}$ concentrations) and blood pressure and / or cholesterol level has been studied in Korean children by Kim et al (2005). In the latter study by Ching et al (2018), no significant correlation was obtained between blood $\mathrm{Pb}$ level and blood pressure or cholesterol while the urine $\mathrm{Hg}$ level was positively associated with the serum cholesterol thus becoming a risk factor of $\mathrm{myocardial}$ infarction and coronary/cardiovascular diseases. Urinary creatinine has also been found as a strong predictor of total urinary arsenic as dimethyl arsenic acid in adults (Basu et al., 2011).

In previous publications, we had reported on the anthropometric predictive equations for percentage body fat in Nigerian women using some of the anthropometric results now presented (Oketayo and Ojo, 2011) while another paper reported the evaluation of the nutritional status using body fat, physiological and biochemical parameters in the same set of Nigerian women (Ojo et al., 2011).

This present report compared two methods of body fat estimation and considered the possible correlations between the level of selected toxic metals in the blood and some physiological/biochemical parameters of nutritional importance in Nigerian women. This is with a view to finding links between environmental exposure to exogenous chemicals and adverse health effects. The study provides the levels of these elements as well as nutritional status of the subjects and determines the relationship as possible diagnostic tools for predicting their impacts.

\section{MATERIAL AND METHODS}

Subject description

Sixty-two Nigerian women (aged between 18 and 52 years) with known exposure to vehicular elemental pollution were purposively selected. An initial population of 300 was surveyed but 81 subjects were selected; some dropped out and only 63 subjects completed the study. Selected subjects were non-pregnant, non-lactating and nonsmoking; they were either traders having their shops and stalls close to busy bus stops, petrol station attendants or traffic wardens. Ethical clearance was obtained from the Ethics and Research Committee of the Obafemi Awolowo University Teaching Hospital Complex before the commencement of the work. Written consent was also obtained from each subject before her recruitment into the study. Physical and medical examinations were conducted and a detailed questionnaire was administered to each subject.

\section{Sample Collection}

Anthropometry

Anthropometry measurements were made in accordance with WHO (2003) guidelines. Subjects' heights were measured to the nearest 0.1 $\mathrm{cm}$ while the body weight was measured to the nearest $0.1 \mathrm{~kg}$. Body mass index (BMI) was calculated as weight $(\mathrm{kg})$ divided by the square of height $\left(\mathrm{W} / \mathrm{H}^{2}\right)$. The subjects were then stratified into Underweight (BMI $\leq 18.5)$, Normal (BMI > 18.5 but $\leq 25)$, Overweight $(\mathrm{BMI}>25$ but $\leq 30)$, and Obese $(\mathrm{BMI}>30)$ groups using NIH / WHO (2004) definitions.

Skinfold thickness such as biceps, triceps, scapular, subscapular, suprailiac and abdominal was determined using Langre calipers while forearm, neck, wrist, waist and hip circumference was measured with a standard tape rule.

\section{Biochemical Parameters}

Body fat was determined using Stable Isotope Dilution (SID) techniques (IAEA, 2009). The Bioelectrical Impedance Analytical (BIA) technique, which involves the use of BF- 350 Tanita body composition Analyzer (Tanita, 1999) to compute body fat from the subject's impedance, gender, height, fitness level, age and weight. The second method - an isotope dilution 
method - involved the ingestion of $\mathrm{D}_{2} \mathrm{O}$ and the determination of deuterium in saliva before (baseline) and in post-dose after its equilibration (IAEA 2009). The saliva samples were kept in a freezer at $-20^{\circ} \mathrm{C}$ until determination of deuterium enrichment by Fourier Transform Infrared (FTIR) Spectrometry.

Blood samples: Ten (10) $\mathrm{ml}$ of venous blood was collected from each subject through ante-cubical venipuncture (using a $10 \mathrm{ml}$ syringe and a $21 \mathrm{G}$ needle) and the blood was discharged slowly without the needle into two separate $5 \mathrm{ml}$ heparinized bottles.

Packed cell volume was determined using a 41A2502 capillary tubes plain-glass heamatocrit reader after spinning with haematocrit centrifuge (Hawksley). The plasma for each specimen was separated, using a disposable Pasteur pipette, into a clean aliquot bottle and stored frozen at $-20{ }^{\circ} \mathrm{C}$. Blood samples for elemental analysis were thawed, lyophilized and sterilized with between 20 and 30 KGy of gamma irradiation using Co- 60 from the Gamma cell 220 irradiator. The wet-to-dry mass ratio of each sample was thereafter calculated. The systolic and diastolic blood pressures (BP1 \& $\mathrm{BP} 2$, respectively) were measured by qualified medical personnel using a calibrated manual sphygmomanometer.

Urine Samples: Spot urine samples were collected from the subjects into sterile universal bottles, kept under ice storage and frozen at -20 ${ }^{\circ} \mathrm{C}$ until analyzed for urinary creatinine.

Urine Samples: Spot urine samples were collected from the subjects into sterile universal bottles, kept under ice storage and frozen at $-20{ }^{\circ} \mathrm{C}$ until analyzed for urinary creatinine.

\section{Analytical procedure}

Laboratory Determination of Biochemical Parameters

Total cholesterol and HDL-cholesterol in the plasma were assayed by enzymatic methods using
RANDOX kits. LDL-cholesterol value was obtained using Friedwald formula:

LDL-C $=$ Total Cholesterol - HDL-C Triglyceride / 2.22

In vitro determination of triglycerides in plasma was determined by the enzymatic method using RANDOX kits.

Creatinine levels in both plasma and urine were determined by optical absorbance measurement at $500 \mathrm{~nm}$. Creatinine clearance was calculated using the expression:

$\mathrm{Cr} . \mathrm{Cl}(\mathrm{ml} / \mathrm{min})=\frac{(140-a g e[y r]) \times(w t[\mathrm{~kg}])}{72 \times \operatorname{serumCr}[\mathrm{mg} / \mathrm{dl}]} \times 90 \%$

Uric acid in urine was determined by the enzymatic colorimetric method [RANDOX, kit]. Precision controls at low, normal, high as well as accuracy control using the RANDOX brand were included in all batch analyses.

\section{Elemental Analysis of Blood Samples}

The levels of lead, arsenic, selenium, cadmium, copper and zinc in the blood samples were determined using Inductively Coupled Plasma Spectrophotometer (ICP-MS). Total Mercury in blood was determined using Direct Mercury Analyzer (DMA).

\subsection{Statistical analysis}

Pearson's product moment correlation was determined among all the parameters using Excel software, and the significance of the correlations were determined using the table of critical values for Pearson $r$ provided by the University of New England, Armidale, Australia. The correlations were determined based on the values of physiological and biochemical parameters reported in Ojo et al. (2011)

\section{RESULTS AND DISCUSSION}

The descriptive statistics of the subjects' body fat, BMI, skin-fold measurement for the chin, bicep, tricep, scapular, sub-scapular, abdominal, suprailiac and circumference of the neck, forearm, wrist, abdomen, waist, hip and waist to hip ratio are presented in table 1 . 


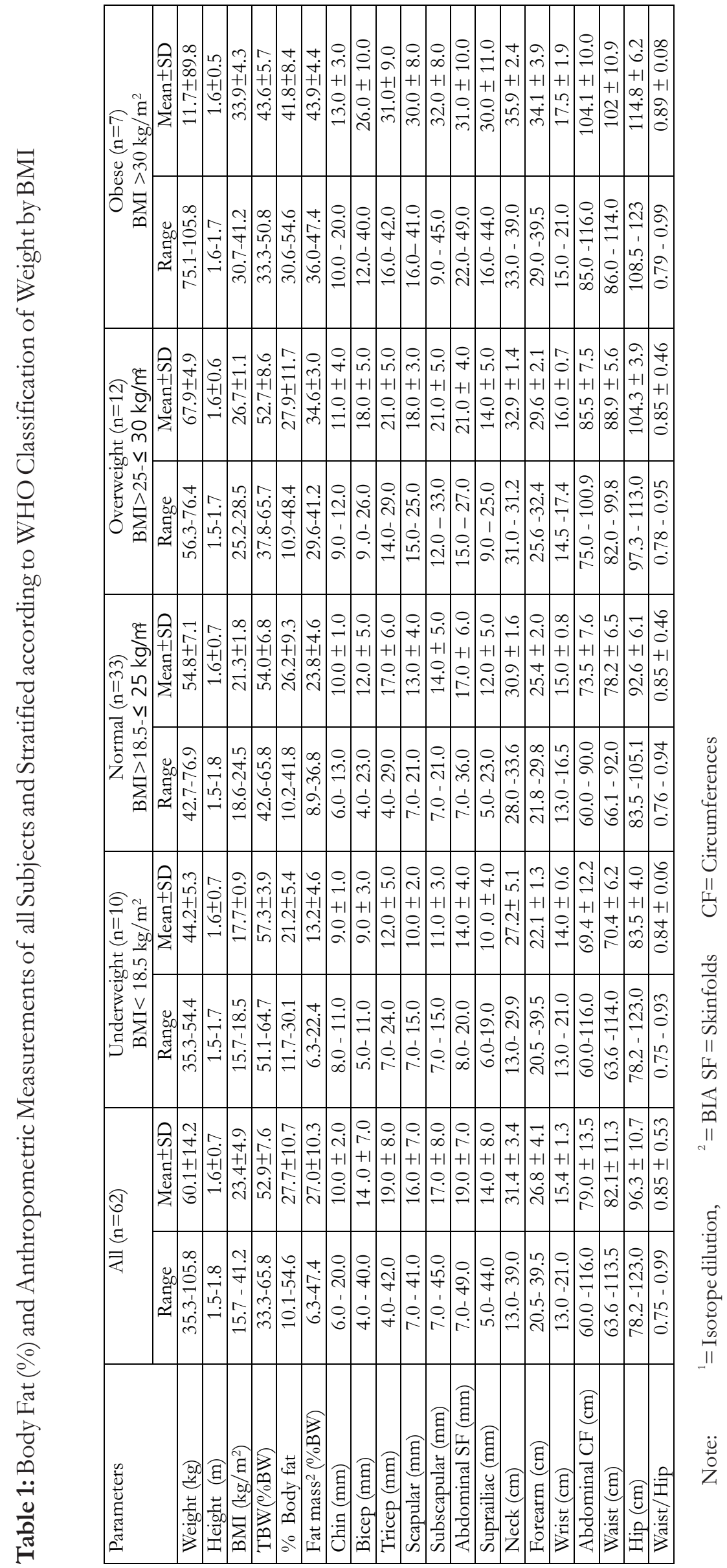


The BMI result indicated that $16.1 \%$ of the subjects were underweight, $53 \%$ were normal, $19.3 \%$ were overweight while $11.3 \%$ were obese using the WHO classification. The percentage body fat of the subjects estimated by isotope dilution ranged from 10.1 to 54.6. There was an excellent correlation $\left(\mathrm{r}^{2}=0.9999\right)$ between the measured $\mathrm{D}_{2} \mathrm{O}$ enrichment by FTIR and the calculated $\mathrm{D}_{2} \mathrm{O}$ in the saliva. Thus, the isotope dilution procedure is validated for the calculation of body water and subsequently the calculation of body fat. Results for \% body fat (6.3 to 47.4) obtained by the bio-impedance technique correlated significantly $(\mathrm{r}=0.517$ at 0.01 level) with those obtained by the stable isotope method, indicating that either method could be used for body fat estimation, especially if the Bioelectrical Impedance Analysis method could be standardized regularly. The bio-impedance method is however simpler to operate once the equipment is available and would be preferred in a third world country with limited infrastructural facilities for research. As indicated earlier (Oketayo and Ojo 2011), there were significant correlations between BMI or body fat and each of the hip, forearm, abdominal and wrist circumferences such that the circumference measurements could be used to predict nutritional status and body fat in Nigerian women. Two certified whole blood materials were analyzed using the same digestion and analytical procedures used for freeze dried blood samples from our subjects. The result presented in table 2 indicated a very good agreement between the laboratory results and the certified values for the seven elements determined in this study.

Table 2: Results obtained for Reference Materials used for Quality Control

\begin{tabular}{|l|l|l|l|l|}
\hline \multirow{2}{*}{ Element } & \multicolumn{2}{|l|}{$\begin{array}{l}\text { PT-WB1:Lyophilised Whol e Human Blood } \\
\text { Sample }\end{array}$} & \multicolumn{1}{l}{$\begin{array}{l}\text { L1-Seronom (Norway) Trace Elements Whole } \\
\text { Blood Sample }\end{array}$} \\
\cline { 2 - 5 } & Certified value & Laboratory value & Certified value & Laboratory value \\
\hline & \multicolumn{5}{|c|}{ Mean $\pm \mathrm{SD}$} \\
\hline $\mathrm{Pb}(\mathrm{ng} / \mathrm{g})$ & $159.0 \pm 16.0$ & $160.0 \pm 13.0$ & $23.0 \pm 6.0$ & $31.0 \pm 5.0$ \\
\hline $\mathrm{Cd}(\mathrm{ng} / \mathrm{g})$ & $3.3 \pm 0.9$ & $2.6 \pm 0.3$ & $0.7 \pm 0.3$ & $0.4 \pm 0.1$ \\
\hline $\mathrm{As}(\mathrm{ng} / \mathrm{g})$ & $8.5 \pm 0.7$ & $8.3 \pm 0.9$ & $1.8 \pm 0.4$ & $2.2 \pm 0.4$ \\
\hline & $0.32 \pm 0.04$ & $0.36 \pm 0.03$ & $0.078 \pm 0.005$ & $0.079 \pm 0.002$ \\
\hline $\mathrm{Cu}(\mu \mathrm{g} / \mathrm{g})$ & $2.05 \pm 0.25$ & $1.79 \pm 0.10$ & $0.564 \pm 0.033$ & $0.533 \pm 0.006$ \\
\hline $\mathrm{Zn}(\mu \mathrm{g} / \mathrm{g})$ & $33.9 \pm 4.2$ & $33.7 \pm 2.0$ & $5.5 \pm 0.3$ & $5.2 \pm 0.15$ \\
\hline $\mathrm{Hg}(\mu \mathrm{g} / \mathrm{g})$ & $7.8 \pm 0.9$ & $6.73 \pm 1.40$ & - & - \\
\hline
\end{tabular}


Table 3: Level of Heavy Metals in the Subjects' Blood and WHO limit

\begin{tabular}{|c|c|c|c|c|c|c|c|}
\hline \multirow{2}{*}{ 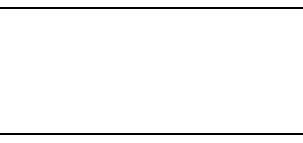 } & & $\mathrm{Cd}$ & $\mathrm{Hg}$ & $\mathrm{Pb}$ & Se & $\mathrm{Cu}$ & $\mathrm{Zn}$ \\
\hline & \multicolumn{3}{|c|}{$\mathrm{ng} / \mathrm{ml}$} & \multicolumn{4}{|c|}{$\mu \mathrm{g} / \mathrm{ml}$} \\
\hline All Subjects (No) & 62 & 62 & 61 & 61 & 62 & 62 & 62 \\
\hline Max. & 13.0 & 0.7 & 13.5 & 150.9 & 1.1 & 2.3 & 10.7 \\
\hline Min. & 0.8 & 0.04 & 1.5 & 24.6 & 0.2 & 0.8 & 3.6 \\
\hline Mean & 3.9 & 0.2 & 4.1 & 68.3 & 0.4 & 1.1 & 5.9 \\
\hline Std dev. & 2.8 & 0.2 & 2.5 & 26.2 & 0.2 & 0.3 & 1.3 \\
\hline $\begin{array}{l}\text { Underweight } \\
\text { (No) }\end{array}$ & 10 & 10 & 10 & 10 & 10 & 10 & 10 \\
\hline Max. & 6.0 & 0.5 & 3.9 & 131.2 & 0.5 & 2.3 & 9.5 \\
\hline Min. & 1.4 & 0.04 & 1.7 & 39.6 & 0.2 & 0.9 & 3.6 \\
\hline Mean & 3.0 & 0.3 & 2.8 & 70.9 & 0.4 & 1.3 & 5.8 \\
\hline Std dev. & 1.3 & 0.2 & 0.66 & 27.3 & 0.1 & 0.6 & 1.7 \\
\hline $\begin{array}{c}\text { Normal } \\
(\mathrm{No})\end{array}$ & 31 & 31 & 30 & 30 & 31 & 31 & 31 \\
\hline Max. & 13.0 & 0.7 & 13.5 & 131.6 & 0.6 & 1.3 & 10.7 \\
\hline Min. & 1.2 & 0.04 & 1.5 & 30.8 & 0.2 & 0.9 & 4.1 \\
\hline Mean & 4.9 & 0.2 & 4.9 & 66.7 & 0.4 & 1.0 & 5.9 \\
\hline Std dev. & 3.4 & 0.2 & 3.2 & 21.6 & 0.1 & 0.1 & 1.2 \\
\hline $\begin{array}{c}\text { Overweight } \\
(\mathrm{No})\end{array}$ & 14 & 14 & 14 & 14 & 14 & 14 & 14 \\
\hline Max. & 8.6 & 0.6 & 5.6 & 150.9 & 1.1 & 1.5 & 8.5 \\
\hline Min. & 1.4 & 0.1 & 2.2 & 24.6 & 0.2 & 0.9 & 4.0 \\
\hline Mean & 3.1 & 0.2 & 3.5 & 70.2 & 0.5 & 1.1 & 6.0 \\
\hline Std dev. & 1.9 & 0.1 & 1.1 & 36.2 & 0.3 & 0.2 & 1.4 \\
\hline $\begin{array}{c}\text { Obese } \\
(\mathrm{No})\end{array}$ & 7 & 7 & 7 & 7 & 7 & 7 & 7 \\
\hline Max. & 4.0 & 0.3 & 4.7 & 111.7 & 0.7 & 1.3 & 8.4 \\
\hline Min. & 0.8 & 0.1 & 2.4 & 35.5 & 0.3 & 0.8 & 4.3 \\
\hline Mean & 2.6 & 0.2 & 3.6 & 63.1 & 0.4 & 1.1 & 6.2 \\
\hline Std dev. & 1.2 & 0.1 & 0.9 & 24.6 & 0.1 & 0.2 & 1.3 \\
\hline $\begin{array}{c}\text { WHO Blood } \\
\text { concentration limit }\end{array}$ & $<10.0$ & $<0.3$ & $<5.0$ & $<10.0$ & $<0.2$ & - & - \\
\hline
\end{tabular}

Table 3 contained the metal content of the subjects' blood samples. Four percent (4\%), $11 \%$, $19.3 \%$ and $98.4 \%$ of the subjects had their blood arsenic, lead, mercury and selenium levels, respectively in excess of the WHO recommended values while others were within. Heavy metals such as mercury, plutonium, and lead are toxic metals that have no known vital or beneficial effect on organisms. Their accumulation over time in the bodies of animals can cause serious illness (Reena et al., 2011). Mercury in the mother's body can be passed to the fetus, where it moves into fetal brain. Once mercury enters the human body, it can remain for months (NRC, 2000).
The choice of tissues to be used as an index for intake levels of heavy metals in the body depends on the expected exposure pattern, the rate of contamination and the metal species involved under steady state conditions. When lead $(\mathrm{Pb})$ enters the body, it travels through the blood to the soft tissues such as brain, liver and kidneys. In adults, most lead taken into the body is excreted, with a small amount stored in bones and teeth, where it can accumulate with repeated exposure (ATSDR, 2000; EPA, 2000b). For heavy metals like $\mathrm{Pb}$ and $\mathrm{Hg}$, hair and nails are regarded as the most suitable indicators of intake levels. Age, health status, geographical location and sample preparation affect the uptake of these metals by 
hair (Norman, 1970). Although, Chen et al(2007)'s finding support the hypothesis that dietary selenium intake may reduce the incident of arsenic-related premalignant skin lesions among population exposed to arsenic through drinking water. Values of the various physiological and biochemical parameters have been previously published and discussed (Ojo et al., 2011).The Pearson's correlation among these important parameters of nutritional importance, anthropometric variables and levels of the seven heavy metals in subjects' blood is presented in table 4.

Table 4: Significant Correlations $(\mathrm{p}<0.05)$ between the Subjects' Elemental Blood levels and Parameters of Nutritional Status

\begin{tabular}{|c|c|c|c|c|c|}
\hline & \multicolumn{5}{|c|}{ Nutritional status / Subjects } \\
\hline Elements & $\begin{array}{l}\text { All } \\
(\mathrm{n}=62)\end{array}$ & $\begin{array}{l}\text { Underweight } \\
(\mathrm{n}=10)\end{array}$ & $\begin{array}{l}\text { Normal } \\
(\mathrm{n}=31)\end{array}$ & $\begin{array}{l}\text { Overweight } \\
(\mathrm{n}=14)\end{array}$ & $\begin{array}{l}\text { Obese } \\
(\mathrm{n}=7)\end{array}$ \\
\hline As & $\begin{array}{l}\text { TC }(0.27), \\
\text { P.Cr }(0.28), \\
\text { Cr.Cl }(-0.26) \text {, } \\
\text { U.Cr }(-0.36) \text {. }\end{array}$ & $\begin{array}{l}\text { Forearm CF (-0.73), } \\
\text { TC }(0.64), \\
\text { P.Cr }(0.71) \text {, } \\
\text { Cr.Cl }(-0.71) \text {, } \\
\text { TC / HDL-C (0.64) }\end{array}$ & $\begin{array}{l}\text { BP1 (0.36), } \\
\text { U.Cr }(-0.51)\end{array}$ & None & $\begin{array}{l}\text { P.Cr }(0.77) \text {, } \\
\text { Cr.Cl }(-0.79)\end{array}$ \\
\hline $\mathrm{Cd}$ & $\begin{array}{l}\text { Body fat }(-0.25) \text {, } \\
\text { Abdominal CF (-0.29), } \\
\text { Cr.Cl }(-0.31)\end{array}$ & $\begin{array}{l}\text { LDL-C (0.64), } \\
\text { TC }(0.63)\end{array}$ & None & $\begin{array}{l}\text { Waist CF (-0.59), } \\
\text { Waist / Hip }(-0.74)\end{array}$ & PCV (-0.84) \\
\hline $\mathrm{Cu}$ & Neck CF $(-0.31)$ & U.Cr $(-0.67)$ & $\begin{array}{l}\text { Scapular SF (-0.50), } \\
\text { Waist CF }(-0.38), \\
\text { Waist / Hip }(-0.39)\end{array}$ & $\begin{array}{l}\text { Abdominal SF } \\
(-0.56)\end{array}$ & None \\
\hline $\mathrm{Hg}$ & $\begin{array}{l}\text { BP1 }(0.26) \\
\text { TG }(-0.29)\end{array}$ & None & $\begin{array}{l}\text { Age }(0.36), \\
\text { Height }(0.36), \\
\text { Weight }(0.38), \\
\text { Body fat }(0.39)\end{array}$ & LDL-C (0.65) & $\begin{array}{l}\text { TG }(0.77), \\
\text { TC }(0.57)\end{array}$ \\
\hline $\mathrm{Pb}$ & $\begin{array}{l}\text { PCV (0.29), } \\
\text { Cr.Cl (-0.27), } \\
\text { LDL-C / HDL-C (0.38) }\end{array}$ & Wrist CF (0.67) & $\begin{array}{l}\text { Height }(-0.38), \\
\text { Weight }(-0.43), \\
\text { Hip }(-0.38), \\
\text { Abdominal CF }(-0.40) \\
\end{array}$ & $\begin{array}{l}\text { Scapular SF }(0.75) \\
\text { HDL-C/LDL-C }(0.54)\end{array}$ & $\begin{array}{l}\text { Age }(0.79) \text {, } \\
\text { TBW (0.83), } \\
\text { FFM (0.83) }\end{array}$ \\
\hline $\mathrm{Se}$ & BP2 (0.26) & None & None & $\begin{array}{l}\text { BP1 (0.59), } \\
\text { BP2 (0.61), } \\
\text { Biceps SF (-0.72) }\end{array}$ & None \\
\hline $\mathrm{Zn}$ & $\begin{array}{l}\text { PCV (0.31), } \\
\text { TG }(0.33) \text {, } \\
\text { UA }(0.24)\end{array}$ & UA (0.64) & $\begin{array}{l}\text { BP2 (0.39), } \\
\text { PCV }(0.44)\end{array}$ & $\begin{array}{l}\text { Waist CF }(-0.70) \text {, } \\
\text { Waist / Hip (-0.72), } \\
\text { TG }(0.56)\end{array}$ & None \\
\hline
\end{tabular}

Value in parenthesis $=$ Correlation coefficient legend should also explain all the abbreviations

Arsenic (As): The element correlated positively with blood $\mathrm{Hg}$ in all the nutritional status groups, except in the obese. Arsenic correlated positively with plasma creatinine and negatively with creatinine clearance in both underweight and obese groups (Table 4). Arsenic acid, furthermore, correlated positively with systolic blood pressure and negatively with urinary creatinine in normal subjects alone; positively with the ratio TC/HDL$\mathrm{C}$ and TC in underweight group alone. In agreement with the present observation, Basu et al (2011) had earlier observed a strong positive correlation between urinary creatinine and arsenic acid. There was no significant correlation whatsoever between blood As and any of the biomarkers in the overweight group.
Cadmium: Blood Cadmium positively correlated with blood selenium in normal subjects, with arsenic in underweight group and with Zinc in the overweight group. The correlation between these heavy metals might indicate the same or similar anthropogenic source of the metals. There was no correlation with any biomarker in the obese group. Blood cadmium did not correlate with any of the biochemical parameters in normal and overweight groups. However, it correlated positively with TC and LDL-C in underweight subjects and negatively with PCV in obese subjects.

Copper: The liver is the main storage organ of copper as a constituent of some metallothioneins. 
It occurs in various complex forms loosely bound to albumin, amino acids and to an alpha 2globulin, ceruloplasmin. Blood levels of this essential element, $\mathrm{Cu}$, did not have any significant correlation with any other element or with any biomarker in any of the nutritional status groups. The only exception was the significant negative correlation with urinary creatinine in the underweight group.

Mercury: Blood mercury correlated with blood As in all the nutritional status groups, except in obese subjects. This again may indicate a common anthropogenic source of these two heavy metals. There was no significant correlation with any biomarker in the underweight group but a positive correlation with body fat in normal group alone; with TC and LDL-C in overweight group alone and with triglycerides in obese group alone. Correlation between urinary $\mathrm{Hg}$ level and serum cholesterol had been reported earlier by Kim et al., (2005). The correlation pattern between blood $\mathrm{Hg}$ and body fat in underweight subjects, though not significant, was actually inverse of that observed in the normal subjects as indicated in figure 1.

Lead: There was also no correlation between blood $\mathrm{Pb}$ and nutritional parameters in underweight and normal subjects. However in the overweight group, blood $\mathrm{Pb}$ correlated positively with the HDL-C / LDL-C ratio and scapular skinfolds (Sf) and the obese group in which age, total body water and fat free mass correlated positively with blood $\mathrm{Pb}$. This may indicate bioaccumulation of Pb. Kim et al., (2005) did not observe any correlation between $\mathrm{Pb}$ and blood pressure or cholesterol and did not investigate the HDL-C / LDL-C ratio. This would therefore be the first indication that overweight and obese people may be subject to ill effects of exposure to this metal than normal subjects.

Selenium: Also, the only significant correlation with the biomarkers was the positive correlation with both systolic and diastolic blood pressure observed only in the overweight group. Selenium is however an essential element, necessary in very minute quantities by man for its antioxidant activities as well its being a vital component of some antioxidant enzymes such as glutathione peroxidase.

Zinc: $\mathrm{Zn}$ is stored in form of metallothioneins and proteins which are the neural growth factor (NGF), gustin of the saliva and cold precipitable protein of the plasma. It is believed to possess anti-oxidant properties, which protect against premature aging of the skin and muscles of the body. It has also been discovered to be very effective in accelerating wound healing. Also for the biochemical markers, blood $\mathrm{Zn}$ correlated with plasma creatinine and diastolic blood pressure (BP2) only in normal subjects; with uric acid in underweight only; and with triglycerides only in overweight group. Zinc can be found in man as a coenzyme of antioxidants and metabolic enzymes.

Table 5a: Significant $(\mathrm{p}<0.05)$ Correlations between Age / BMI; Some Biomarkers and Anthropometric Parameters in Nigerian Women

\begin{tabular}{|c|c|c|c|}
\hline $\begin{array}{l}\text { PARA- } \\
\text { METER }\end{array}$ & ELEMENTAL & BIOCHEMICAL & ANTHROPOMETRY \\
\hline Age & $\begin{array}{l}\text { Normal: } \mathrm{Hg}(+) \\
\text { Underweight: None } \\
\text { Overweight: None } \\
\text { Obese: } \mathrm{Pb}(+) \\
\text { All: None }\end{array}$ & $\begin{array}{l}\text { Normals: BMI, BF, BP1, BP2 (+) } \\
\text { Underweight: UA(-) } \\
\text { Overweight:HDL-C/LDL-C, } \\
\text { TC/HDL-C, LDL-C, U.Cr }(+) \\
\text { Obese:TC/HDL-C (+), BP2 (+) } \\
\text { All:\%BF, BP1, BP2 }\end{array}$ & $\begin{array}{l}\text { Normals:Wt, Ht }(+) \\
\text { Underweight: None } \\
\text { Overweight: None } \\
\text { Obese: None } \\
\text { All: ALL Parameters except wrist cm, } \\
\text { chin sf, and height }\end{array}$ \\
\hline BMI & $\begin{array}{l}\text { Normal: None } \\
\text { Underweight:None } \\
\text { Overweight:None } \\
\text { Obese:None } \\
\text { All:None }\end{array}$ & $\begin{array}{l}\text { Normals: \%BF (+) } \\
\text { Underweight:LDL-C/HDL-C, TC } \\
\text { C, P.Cr (+),:\%BF (+) } \\
\text { Overweight: TG }(+),: \% \mathrm{BF}(+) \\
\text { Obese:None } \\
\text { All:\%BF, Cr.Cl, BP1, BP2 }\end{array}$ & $\begin{array}{l}\text { Normal: Age, Wt, } 3 \text { sf, 4cf (+) } \\
\text { Wnderweight:Wt }(+) \\
\text { Overweight: Ht }(-) \\
\text { Obese:Wt, Chin sf, Wrist }(+) \\
\text { All (+): ALL Parameters, except } \\
\text { Waist/Hip }\end{array}$ \\
\hline
\end{tabular}

Note: $\mathrm{sf}=$ Skinfolds $\mathrm{cf}=$ Circumferences 
Table 5b: Numerical Values for some Correlations of Elements with Biomarkers showing Influence of Nutritional Status

\begin{tabular}{|l|l|l|l|l|l|}
\hline & $\begin{array}{l}\text { Normal Subjects } \\
\mathrm{n}=31\end{array}$ & $\begin{array}{l}\text { Underweight } \\
\text { Subjects } \\
\mathrm{n}=10\end{array}$ & $\begin{array}{l}\text { Overweight Subjectsbese Subjects } \\
\mathrm{n}=14\end{array}$ & $\begin{array}{l}\text { All subjects } \\
\mathrm{n}=62\end{array}$ \\
\hline As vs P.Cr & $0.202(\mathrm{NS})$ & $0.712^{*}(0.02)$ & $0.2446(\mathrm{NS})$ & $0.774^{*}(0.02)$ & $0.277^{*}(0.05)$ \\
\hline Hg vs \%BF* & $0.386^{*}(0.05)$ & $-0.245(\mathrm{NS})$ & $0.193(\mathrm{NS})$ & $0.301(\mathrm{NS})$ & $0.155(\mathrm{NS})$ \\
\hline Pbvs LDL/HDL & $0.159(\mathrm{NS})$ & $0.564(0.01)$ & $0.539^{*}(0.05)$ & $0.438(\mathrm{NS})$ & $0.377^{* *}(0.01)$ \\
\hline Zn vs UA* & $0.152(\mathrm{NS})$ & $0.638^{*}(0.05)$ & $0.24(\mathrm{NS})$ & $0.192(\mathrm{NS})$ & $0.239(0.01)$ \\
\hline
\end{tabular}

Note: Values in brackets are the levels of significance $*=$ Significant at 0.05 level $* *=$ significant at 0.01 level

Table 4 is a summary of the correlation pattern between each of the seven elements (column 1) and other elements (column 2), the various biochemical markers (column 3), and anthropometric parameters (column 4) - for the four different Nutritional Status Groups, as well as for all the subjects combined. Similar data are presented in table $5 \mathrm{a}$ for correlations involving age, BMI,-biochemical markers and anthropometric parameters. The parameters with significant correlations are indicated in front of the group where such correlation is found. Positive Correlations are indicated with the "+" while negative correlations are shown with the "-" symbol. Where there is no correlation, this is indicated by "None". Tables $5 \mathrm{~b}$ also contain other interesting correlations involving all the subjects taken together as a group. It is observed that blood arsenic levels correlated positively with total cholesterol (TC) in underweight as well as creatinine levels in both urine and plasma for the obese (Table 5); while blood mercury levels correlated negatively with TG $(\mathrm{n}=62, \mathrm{r}=0.273$ and -0.285 respectively). Cadmium concentration in subjects' blood $(\mathrm{n}=62)$ also correlated negatively with body fat $(\mathrm{r}=0.252)$ and creatinine clearance $(r=-0.309)$. Similarly, at $p<$ 0.05 , blood lead level (BLL) correlated positively with PCV ( $\mathrm{r}=0.292)$ and LDL-C / HDL-C $(\mathrm{r}=$ $0.379)$ but negatively with $\mathrm{Cr} . \mathrm{Cl}(\mathrm{r}=-0.267)$. In the obese subjects alone, positive significant correlation was found between BLL and age $(r=$ 0.792 ) as well as the length of exposure.

In the subjects with normal BMI, the blood mercury content correlated positively with age, weight, height and body fat $(\mathrm{p}<0.05, \mathrm{r}$ values between 0.364 and 0.761 ). This is an indication that any alteration in the levels of these metals in blood could directly or indirectly influence the values of some of the physiological and biochemical parameters of nutritional importance in the subjects observed

\section{CONCLUSION}

It has been established in this work that the concentrations of $\mathrm{As}, \mathrm{Pb}, \mathrm{Hg}$ and $\mathrm{Se}$ (out of the seven elements determined) in the whole blood of some subjects were above the WHO limits. Clear relationships have also been observed between the levels of these metals and some physiological/biochemical parameters of nutritional importance as well as anthropometry, generally and on the basis of their nutritional status. This suggests that interactions between trace elements and these important physiological/ biochemical parameters are influenced by the nutritional status of the individual subjects. This may also provide a basis for determining the effects of these toxic elements on the exposed subjects.

\section{ACKNOWLEDGEMENT}

This work was supported by the International Atomic Energy Agency, Vienna (Research Contract RC 13248). We appreciate the technical supports from Prof Milena HORVAT with the elemental analyses at Josef Stefan Institute, Slovenia; and Theo ADOM with FTIR analyses at the Radiological and Medical Sciences Research Institute, Ghana Atomic Energy Commission, Accra. We thank the Divisional Police Officer at the More Police Station, Ile-Ife, Osun State, Nigeria for access to volunteer Traffic policewomen.

\section{REFERENCES}

Adekunle, I.M., Ogundele J.A., Oguntoke, O. and Akinloye, A.O. 2009. Assessment of blood and urine levels of some pregnant women residing in Lagos, Nigeria. Environ. Monitor. Assesssm., 170(1-4): 467 - 
474.

Agbo, S. 1997. Effect of lead poisoning in children in proceeding of a workshop on vehicular emission and lead poisoning in Nigeria edited by A. A. Falomo and C.C. Chikwendu, Organized by Friends of the Environments (FOTE) Lagos: 20-28.

Agency for Toxic Substances and Disease Registry (ATSDR). 1999. Lead toxicity: Physiologic effect. www.atsdr. cdc.gov/HEC/CSEM/lead/physiologic _effects.html.

Agency for Toxic Substances and Disease Registry (ATSDR) 2000. Toxicological Profile for Cadmium. Agency for Toxic Substances and Disease Registry, Atlanta,GA, http:// www.atsdr. cdc.gov/toxprofiles/tp5.html.when

Antham, R., Mamopeli, M., Rietha, O. 2006. Environmental quality and protection, In: Air quality management and climate change, Publication Series B, Book 5, pp.12.

Basu, A., Mitra, S., Chung, J., Guha, Mazumder D, N., Ghose, N., Kaiman, O.A. 2011. Creatinine, diet, micronutrients, and arsenic methylation in West Bengal, India. Environ Health Perspect, 119: 1308-1313.

Chen Y., Hall M., Graziano J.H., Slarkorich V., Geen A.V., Parvez F and Ahsan H 2007. A prospective study of blood selenum levels and the risk of arsenic-related premalignant skin lesions, cancer. Epidemiol. Biomarkers Prev., 16(2):207-213.

Ching H.L., Yi-Ting H., Cheng-Ching Y., HsinHung C., Ching-Jiunn T., Yuk-Keung L and Ulie Y.H.C. 2018. Association between heavy metal levels and acute ischemic stroke. J. Biomedi. Sc., 25: 49

EPA 2000. Toxics Release Inventory (TRI) Public Data Release Report. Office of Environmental Information, Washington, DC. EPA-260-R-02-003. Accessed online at http://www.epa.gov/tri/ tridata/tri00/pdr/index.htm.

Fakayode, O.S. 2003. Heavy Metal contamination of Roadside top Soil in Osogbonigeria: its relationship to Traffic Density and Proximity to Highway. J. of Env Geol., 44 (2): 23-24.

FDA/EPA (2004).What you need to know about
Mercury in Fish and Shellfish: Advice for women who might become pregnant, women who are pregnant, nursing mothers and young children. Washington DC and Atlanta, GA: Food and drug administration and environmental protection agency, 10-18.

International Atomic Energy Agency. 2009. Assessment of body composition and total energy expenditure in humans using stable isotope technique. IAEA Series No 3

http:/www.iaea.org/publication/Index.h tml: 6-7.

Kim, D.S., Lee, E.H., Yu, S.D., Cha, J.H., Ahn, S.C. 2005. Heavy metal as risk factor of cardiovascular disease--an analysis of blood lead and urinary mercury. J. Prev. Med. Public Health, 38 (4) : 401-407.

Muschack, W.R. 1990. Pollution of Street Run-off Traffic and Local Condition. Science of Total Environment, 93: 419-431.

Norman, M. T. 1970. Environmental and Health, 1:367-405.

National Research Council 2000. Toxicological effects of methyl mercury, National Academy Press, Washington. DC. 200: 8.

National Institutes of Health (NIH)/ World Health Organization (WHO) Guidelines 2004. BMI and ideal weight, American Journal of ClinicalNutrition, 72: 1- 2.

Obioh, I. B., Akeredolu, F.A., Oluwole, A.F. 1993. Air pollution inventorization in relation to impact prediction and emission control, A paper at the international workshop in natural and man-made hazards in Africa, Akeva, Nigeria.

Ogunsola, O.J., Akeredolu, F.A. 1994. Traffic pollution: Preliminary elemental characterization of road side dust in Lagos, Nigeria. The Science of the Total Environment 146/147: 175-187.

Ojo, J.O., Oketayo, O.O., Aboderin, A.O., Salawu, A.A.,Adewusi, S.R.A. 2011. Evaluation of nutritional status using body fat, physiological and biochemical parameters in some Nigerian women. Nutrition and Health, 20: 197-208.

Oketayo, O.O., Ojo, J.O. 2011. Anthropometric predictive equations for percentage body fat in Nigerian women using bioelectrical 
impedance as reference. Ife Journal of Science, 13(2): 363-369.

Reena S., Neetu G., Anuraq M., Rajiv G. 2011. Heavy metals and living systems-A review, 43(3): .246-253.

Tanita Corporation of America (TANITA) 1999. Understanding body fat analysis, Excerpt from the pampllet: 1 - 3 .

US EPA 1997.Exposure factors handbook, EPA/600/P-95/002Fc. Office of Research and Development, U.S.EPA, Washington, DC, http://www.epa. gov/ncea/exposfac.htm.

Vahter, M. 2007. Arsenic exposure in pregnancy effect: Modification by metabolism and nutrition. Journal of Nutrition, 137: 27982804.

Viklander, M. 1998. Particle size distribution and metal content in street sediments. J. Environmental Engr. ASCE 124 (8): 761766.

World Health Organization 2003. Anthropometric test, Top end publication: 1 - 4 . 